\title{
Evaluating the effects of sewage sludge compost applications on the microbial activity, the nutrient and heavy metal content of a Chernozem soil in a field survey
}

\author{
Andrea Farsang ${ }^{1,2}$ (1) $\cdot$ Izabella Babcsányi $^{1} \cdot$ Zsuzsanna Ladányi $^{1} \cdot$ Katalin Perei $^{2,3} \cdot$ Attila Bodor $^{2,3,4}$. \\ Katalin Tímea Csányi ${ }^{1} \cdot$ Károly Barta $^{1}$
}

Received: 30 March 2020 / Accepted: 10 September 2020 / Published online: 17 September 2020

(C) The Author(s) 2020

\begin{abstract}
Sewage sludge contains organic matter and micro and macronutrients which are potentially useful for agricultural usage. However, it can be harmful when containing undesirable amounts of organic pollutants, heavy metals, or pathogens. Our study focused on examining the changes in the extractable nutrient, organic matter and heavy metal contents of a Chernozem soil and the alteration of the soil biological activity as a consequence of low-dose municipal sewage sludge compost applications (0.5 tha). Sampling campaigns were done in 2018 near Újkígyós (SE Hungary) during which composite soil samples (0-30 cm and 30-60 cm) and groundwater samples were collected for assessing changes in the nutrient and heavy metal concentrations as a result of compost amendments' use. Additionally, upper soil $(0-50 \mathrm{~cm})$ and subsoil $(50-80 \mathrm{~cm})$ were sampled for assessing biological parameters, considered to be aerobic and anaerobic soil layers, respectively. Soil samples were analyzed for the basic pedological parameters (pH, organic matter, carbonates and texture), nutrients $\left(\mathrm{K}_{2} \mathrm{O}, \mathrm{P}_{2} \mathrm{O}_{5}, \mathrm{~N}\right.$-forms and organic matter) and heavy metal concentrations following standard extraction procedures. The microbial properties were characterized by colony-forming units (CFUs) and enzyme activity measurements. The results of the nutrient analyses show significantly increased soil-bound $\mathrm{K}_{2} \mathrm{O}, \mathrm{P}_{2} \mathrm{O}_{5}$ and $\mathrm{NO}_{2}{ }^{-}+\mathrm{NO}_{3}{ }^{-}$contents linked to the sewage sludge treatments. However, neither the organic matter nor the heavy metal content varied significantly in the sludge-amended soil compared with a control site. The microbiological analyses revealed that the sewage sludge treatments tended to increase the aerobic CFUs, but not that of the anaerobic microbes. The average catalase enzyme activity in both the aerobic and anaerobic samples and the average dehydrogenase activity only in the aerobic layers showed a slight but not significant increase in the compost-amended soils. Overall, these results convincingly demonstrated that amending soils with low doses of municipal sewage sludge composts (lacking any industrial sources) can be a sustainable fertilizing practice taking advantage of their high $\mathrm{N}$, $\mathrm{P}$ and $\mathrm{K}$ contents that are slowly converted to their bioavailable forms thus preventing their excessive leaching in the groundwater.
\end{abstract}

Keywords Sewage sludge disposal $\cdot$ Soil protection $\cdot$ Nutrient content $\cdot$ Enzyme activity

This paper was selected from the 2nd Conference of the Arabian Journal of Geosciences (CAJG), Tunisia 2019

Responsible Editor: Haroun Chenchouni

Andrea Farsang

farsang@geo.u-szeged.hu

1 Department of Physical Geography and Geoinformatics, University of Szeged, Egyetem utca 2-6, Szeged H-6722, Hungary

2 Institute of Environmental Science and Technology, University of Szeged, Tisza L. krt 132, Szeged H-6720, Hungary

3 Department of Biotechnology, University of Szeged, Közép fasor 52, Szeged H-6726, Hungary

4 Institute of Biophysics, Biological Research Centre, Temesvári krt 62, Szeged H-6726, Hungary

\section{Introduction}

The main by-product of a wastewater treatment plant sewage sludge is rich in organic and inorganic nutrients; hence, it can be applied on agricultural land as an alternative to mineral fertilizers. Land application is an increasingly popular mean of the reuse of sewage sludge as it allows for recycling of valuable components such as organic matter, N, P and other nutrients. Understanding the impacts of sewage sludge treatments is essential in the correct management of agricultural land. Indeed, sewage sludge amendment to the soil modifies the soil's physico-chemical and biological properties, such as plant-available macro-/micronutrient contents and organic matter content. Soil organic matter is a key factor in improving 
or maintaining the physico-chemical (aggregate stability, water holding capacity, cation exchange capacity, etc.) and biological properties of a soil (Aggelides and Londra 2000, Xue and Huang 2013). Hence, amending the soil with external organic material is beneficial and may offset the negative impacts of intensive land management. Nevertheless, some problems may arise from the repeated applications of sewage sludge composts. The heavy metal content in sewage sludge-amended soils may increase, ultimately impairing soil fertility (Pinamonti et al. 1997). Indeed, it is the heavy metal content which primarily restricts the agricultural use of sewage sludge composts to avoid their overaccumulation in the ploughed layer of soils. Several studies have shown that the soil type, the culture plant species, the compost quality and applied doses are the main factors affecting heavy metal contents and availability in agricultural soils (Pinamonti et al. 1997, Abubakari et al. 2017, Qi et al. 2020). Increased extractable amounts of $\mathrm{Zn}$ and $\mathrm{Cd}$ have been observed in sewage sludge-amended soils lasting for a long time even after ceasing sludge applications (McGrath et al. 2000). Hence, the field applications of sewage sludge composts should be carefully managed, and the potentially toxic heavy metals monitored in compost-amended soils.

Besides amending the soil with plant nutrients and organic matter, sewage sludge application can significantly increase the amount of microbial biomass and alter its diversity, can change microbial function and also increase the soil enzyme activities. After an input of soil organic carbon, these changes occur rapidly and mainly affect the topsoil layer $(0-5 \mathrm{~cm})$ (Banerjee et al. 1997, Guo et al. 2016). Increased microbial biomass can improve soil structure through increased formation of soil macroaggregates, which also has an influence on soil organic carbon dynamics (Wang et al. 2017). Nonetheless, tillage can move microorganisms from the microaerophilic or anaerobic layers towards the topsoil, where they can be inactivated or can die due to the high concentration of oxygen, thus affecting microbial diversity (Wang et al. 2017, Dhaliwal et al. 2020).

Activities of dehydrogenase (DH) and catalase (CAT) enzymes in soil are considered ecotoxicological indicators of soil quality and soil health. Monitoring of DH provides information about the microbial oxidation processes of soil organic matter and respiratory activity of soil microbiome. CAT also refers to the presence of metabolically active microorganisms in soil (Achuba and Peretiemo-Clarke 2008). Since both enzymes have a key role in nutrient cycling and detoxification of xenobiotics in soil (Frîncu et al. 2015), DH and CAT can be used to decipher the impacts of the sewage sludge treatments on the soil biological activity (Banerjee et al. 1997, Xue and Huang 2013). Microbial cell counts and enzyme activities, however, do not necessarily correlate because microorganisms can enter a zero or low activity state facing adverse conditions (Bodor et al. 2020). Therefore, DH and CAT indicate certainly active microorganisms, while cell counting in nutrient-rich media can result in biases due to the reactivation of previously dormant bacteria. Or vice versa, microorganisms previously active in soil might not grow on standard laboratory media.

Previous studies investigated metabolic activity in topsoil layers of $0-5$ or $0-10 \mathrm{~cm}$ (Guo et al. 2015). Considering that the fibrous root system of wheat or maize can reach deeper soil layers (Gong et al. 2009), examination of the microbial activity at this depth and deepening of knowledge about the activity of their rhizosphere $(20-30 \mathrm{~cm})$ after sewage sludge application is particularly important.

Our hypotheses are (1) that a typical municipal sewage sludge compost (without any industrial sources) can supply soils with nutrients in a sustainable manner without addition of significant amounts of potentially toxic heavy metals and (2) the organic matter added with composts will improve microbiological properties of amended soils. The aim of the present study is to investigate the impact of low-dose municipal sewage sludge compost $(0.5 \mathrm{t} / \mathrm{ha})$ treatments on the nutrient status, the metal contents and the biological activity in a Chernozem soil.

\section{Materials and methods}

\section{Study area and sampling}

The study area is located near Újkígyós, in southeastern Hungary (Fig. 1) (Ladányi et al. 2018). The whole area is an approximately 25.6 ha arable land, where municipal sewage compost has been applied since 2013 between October and November $(0.5 \mathrm{t} / \mathrm{ha})$ in a rotating manner. In this study, the compost-amended area is a 5.6 ha land that received sewage sludge compost twice in 2013 and in 2017. The sewage sludge was obtained from a small wastewater treatment plant treating municipal wastewater (without any industrial water) from two villages (Újkígyós and Szabadkígyós) with a capacity of 10,800 population equivalent and a wastewater outflow of $1300 \mathrm{~m}^{3} /$ day. The water treatment is comprised of three stages: mechanical cleaning and filtering, biological treatment and aeration. Before use, the sewage sludge (see Table 1) goes through aerobic composting with straw material during at least 6 months. Following the field application of sewage sludge compost, the soil is ploughed until $\sim 30 \mathrm{~cm}$ depth. Winter wheat was produced on the compost-amended area in 2018. The seedbed preparation was identical for the entire area of study. No additional fertilizers are applied on the compostamended site in the years of sewage sludge compost application. The control site undergoes chemical fertilizer application.

The control area has never been affected by compost applications so far. The rate of compost application was calculated 
Table 1 The quality of the applied municipal sewage sludge compost in 2013 and in 2017. The displayed Hungarian threshold for sewage sludge compost applied in agricultural land is specified in the Government Decree No.50/2001. (IV. 3)

\begin{tabular}{|c|c|c|c|}
\hline Parameters & $\begin{array}{l}\text { Compost quality in } \\
2013\end{array}$ & $\begin{array}{l}\text { Compost quality in } \\
2017\end{array}$ & $\begin{array}{l}\text { Hungarian } \\
\text { threshold }\end{array}$ \\
\hline pH (d.w.) & 7.64 & 8.48 & - \\
\hline Dry matter $(\mathrm{mg} / \mathrm{kg})$ & 181000 & 24600 & - \\
\hline Organic matter $(\mathrm{m} / \mathrm{m} \%)$ & 13.2 & 5.7 & - \\
\hline Total nitrogen (mg/kg dry w.) & 59100 & 128700 & - \\
\hline $\begin{array}{l}\text { Total phosphorus } \\
\left(\mathrm{P}_{2} \mathrm{O}_{5} \mathrm{mg} / \mathrm{kg} \text { dry w.) }\right.\end{array}$ & 19500 & 16500 & - \\
\hline $\begin{array}{l}\text { Total potassium }\left(\mathrm{K}_{2} \mathrm{O} \mathrm{mg} / \mathrm{kg} \text { dry }\right. \\
\text { w.) }\end{array}$ & 2560 & 5860 & - \\
\hline $\mathrm{TPH}(\mathrm{mg} / \mathrm{kg})$ & $<25$ & 2588 & 1000 \\
\hline As $(\mathrm{mg} / \mathrm{kg})$ & 67.6 & 15.5 & 25 \\
\hline $\mathrm{Cd}(\mathrm{mg} / \mathrm{kg})$ & 0.53 & $<1$ & 5 \\
\hline $\mathrm{Co}(\mathrm{mg} / \mathrm{kg})$ & $<1$ & 2.31 & 50 \\
\hline $\mathrm{Cr}(\mathrm{mg} / \mathrm{kg})$ & 14.2 & 17.6 & 350 \\
\hline $\mathrm{Cu}(\mathrm{mg} / \mathrm{kg})$ & 81.1 & 103 & 750 \\
\hline $\mathrm{Hg}(\mathrm{mg} / \mathrm{kg})$ & 0.64 & 0.46 & 5 \\
\hline Mo (mg/kg) & 6.74 & 6.35 & 10 \\
\hline $\mathrm{Ni}(\mathrm{mg} / \mathrm{kg})$ & 12.4 & 15.1 & 100 \\
\hline $\mathrm{Pb}(\mathrm{mg} / \mathrm{kg})$ & 18.7 & 16.3 & 400 \\
\hline $\mathrm{Se}(\mathrm{mg} / \mathrm{kg})$ & $<1$ & $<1$ & 50 \\
\hline $\mathrm{Zn}(\mathrm{mg} / \mathrm{kg})$ & 444 & 542 & 2000 \\
\hline $\begin{array}{l}\text { Number of faecal coliform } \\
\text { (per g dry w.) }\end{array}$ & 1213000 & 381000 & - \\
\hline $\begin{array}{l}\text { Number of faecal streptococcus } \\
\text { (per g dry w.) }\end{array}$ & 8820000 & 1320000 & - \\
\hline
\end{tabular}

based on the nutrient $(\mathrm{N}, \mathrm{P}, \mathrm{K})$ content of the compost and the nutrient requirements of cultivated plants and was set to $0.5 \mathrm{t}$ / ha of compost dry weight. Composite samples were collected in March 2018 from the upper soil (0-30 cm) and subsoil (30-
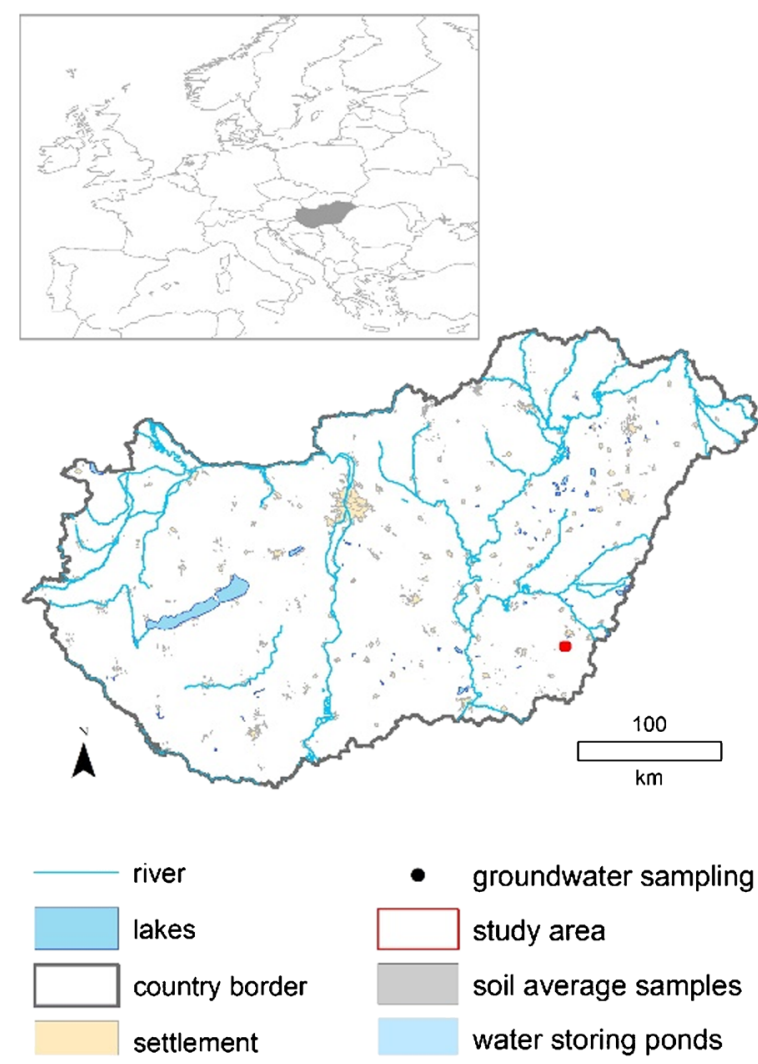
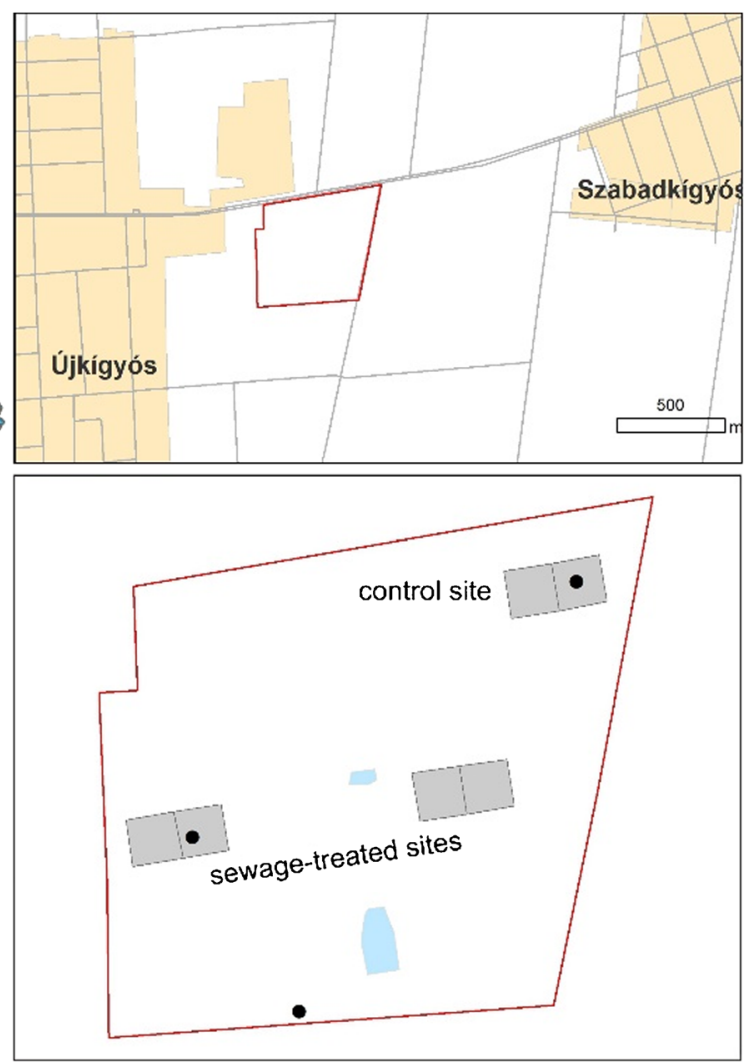

Fig. 1 The map of the study area located near Újkígyós (southeastern Hungary) 
$60 \mathrm{~cm})$ from six sites of $2500 \mathrm{~m}^{2}(50 \times 50 \mathrm{~m})$ within the study area: 4 sewage sludge compost-amended sites and 2 control sites. Each plot was sampled in 20-25 uniformly distributed points with a hand auger and mixed for obtaining a composite sample. For assessing soil biological parameters (heterotrophic bacterial counts, DH and CAT activities), soil samples were also collected from the upper soil $(0-50 \mathrm{~cm})$ and subsoil $(50-80 \mathrm{~cm})$ considered as aerobic and anaerobic soil layers, respectively. Additionally, groundwater samples were taken from boreholes at $2.7 \mathrm{~m}$ depth at three locations within the study area (one affected by compost applications and two control sites) in order to assess dissolved nutrient concentrations and heavy metals.

\section{Analyses of $\mathrm{pH}$, organic matter, nutrients and heavy metals}

The $\mathrm{pH}$ (in d.w.) and the organic matter content of soils were measured according to standard procedures. Briefly, the $\mathrm{pH}$ (d.w.) was determined by a WTW inoLab 720p pH meter in a soil: distilled water ratio of 1:2.5 (MSZ-08-0206-2:1978), the organic matter content was measured by colorimetry using a spectrophotometer (UNICAM Helios Gamma UV-VIS, Thermo Scientific) following $\mathrm{H}_{2} \mathrm{SO}_{4}$-aided oxidation of the organic material with $0.33 \mathrm{M} \mathrm{K}_{2} \mathrm{Cr}_{2} \mathrm{O}_{7}$ (MSZ 2147052:1983). The macronutrients $\mathrm{P}_{2} \mathrm{O}_{5}$ and $\mathrm{K}_{2} \mathrm{O}$ were extracted using ammonium-lactate, while the nitrogen forms $\left(\mathrm{NO}_{2}{ }^{-}+\right.$ $\mathrm{NO}_{3}{ }^{-} \mathrm{N}$ ) were extracted with a $\mathrm{KCl}$ solution. The nutrient content was then determined by a flow injection analysis (FIA) spectrometer (FIA STAR 5000, Foss). Prior to total metal analyses, soil samples were dried in the laboratory at $105^{\circ} \mathrm{C}$ for $24 \mathrm{~h}$ and powdered in an agate ball mill. Powdered soil samples $(0.5 \mathrm{~g})$ were digested in aqua regia (hydrochloric acid:nitric acid $=3: 1$ ) in closed vessels in a microwave oven (Multiwave 3000, Anton Paar ). Groundwater samples were filtered at $0.45 \mu \mathrm{m}$ using cellulose acetate filter membranes. Heavy metals were analyzed using yttrium as an internal standard with an inductively coupled plasma optical emission spectrometer (ICP-OES) (Optima 7000 DV, Perkin Elmer) $( \pm 5 \%)$. Sample treatment and analyses were done in a laboratory accredited by the National Accreditation Body of Hungary (member of the European Accreditation). For quality insurance, the laboratory regularly participates in interlaboratory comparisons for testing accuracy and reproducibility of soil analyses. In-house standards and procedural blanks are also regularly used and checked.

\section{Determination of soil microbial counts}

Modified colony-forming unit (CFU) method of Wu et al. (2013) was used to enumerate viable heterotrophic bacteria both in aerobic and anaerobic layers of sewage-treated and control soils. Homogenized soil samples $(5-5 \mathrm{~g})$ were suspended in $10 \mathrm{~mL}$ of physiological saline solution and shaken for $30 \mathrm{~min}$. Serial dilutions of each suspension were pipetted onto nutritionally rich Luria Bertani (LB) agar plates containing $10 \mathrm{~g} / \mathrm{L}$ Triptone, $10 \mathrm{~g} / \mathrm{L} \mathrm{NaCl}$ and 5 $\mathrm{g} / \mathrm{L}$ yeast extract solidified with $15 \mathrm{~g} / \mathrm{L}$ Bacto agar (Sambrook et al. 1989). Individual colonies were counted after 3 days of incubation at $25{ }^{\circ} \mathrm{C}$. Anaerobic microbial counts were assessed in terms of nitrate-, sulfate- and iron-reducing microorganisms. Although all of these anaerobic microbial groups are able to grow on LB plates, nitrate reducers rapidly respond to the nitrates in LB by blooming. Since nitrate is the most preferred electron acceptor under anaerobic conditions, nitrate-reducing microorganisms can easily overgrow others, thus giving CFUs counted on LB plates as a good estimation for nitratereducer microbial counts. Cell counts of sulfate-reducing microorganisms were estimated by the number of colonies formed on agar plates of modified minimal medium (MM: $0.217 \mathrm{~g} / \mathrm{L} \mathrm{KH}_{2} \mathrm{PO}_{4}, 1.46 \mathrm{~g} / \mathrm{L} \mathrm{K}_{2} \mathrm{HPO}_{4}, 0.585 \mathrm{~g} / \mathrm{L} \mathrm{NaCl}$, $0.125 \mathrm{~g} / \mathrm{L} \mathrm{MgSO}{ }_{4} \cdot 7 \mathrm{H}_{2} \mathrm{O}, 44 \mathrm{mg} / \mathrm{L} \mathrm{CaCl}{ }_{2} \cdot 2 \mathrm{H}_{2} \mathrm{O}, 0.2 \mathrm{mg} /$ $\mathrm{L} \mathrm{ZnSO}_{4} \cdot 7 \quad \mathrm{H}_{2} \mathrm{O}, 0.06 \mathrm{mg} / \mathrm{L} \mathrm{MnCl}_{2} \cdot 4 \mathrm{H}_{2} \mathrm{O}, 0.6 \mathrm{mg} / \mathrm{L}$ $\mathrm{H}_{3} \mathrm{BO}_{3}, 0.4 \mathrm{mg} / \mathrm{L} \mathrm{CoCl}_{2} \cdot 6 \mathrm{H}_{2} \mathrm{O}, 0.02 \mathrm{mg} / \mathrm{L} \mathrm{CuCl} \mathrm{Cu}_{2} \cdot 2$ $\mathrm{H}_{2} \mathrm{O}, 0.04 \mathrm{mg} / \mathrm{L} \mathrm{NiCl} \cdot 6 \mathrm{H}_{2} \mathrm{O}, 0.046 \mathrm{mg} / \mathrm{L} \mathrm{NaMoO}_{4} \cdot 4$ $\mathrm{H}_{2} \mathrm{O}, 14 \mathrm{mg} / \mathrm{L} \mathrm{FeSO}{ }_{4}, 9.3 \mathrm{mg} / \mathrm{L}$ EDTA.2 $\mathrm{H}_{2} \mathrm{O}, 1.6 \mathrm{~g} / \mathrm{L}$ $\mathrm{NH}_{4} \mathrm{Cl}$ ) of Laczi et al. (2015) supplemented with $0.5 \%$ lactate as sole carbon and energy source. For ironreducing CFU counting, $7.9 \mathrm{mg} / \mathrm{L} \mathrm{FeCl}_{3} \cdot 6 \mathrm{H}_{2} \mathrm{O}, 0.1 \mathrm{~g} / \mathrm{L}$ $\mathrm{MgCl}_{2} \cdot 6 \mathrm{H}_{2} \mathrm{O}$ and $0.09 \mathrm{mg} / \mathrm{L} \mathrm{ZnCl} \mathrm{Zn}_{2}$ were used instead of $\mathrm{FeSO}_{4}, \mathrm{MgSO}_{4}$ and $\mathrm{ZnSO}_{4}$, respectively, to avoid available sulfate and sulfate-reducing activity (Farkas et al. 2017). The obtained results were expressed as million CFUs per gram soil.

\section{Determination of soil enzyme activity}

Soil DH activity measurement was performed according to the procedure of Wolinska et al. (2016). Six grams soil sample, $0.12 \mathrm{~g} \mathrm{CaCO}_{3}, 4 \mathrm{~mL}$ distilled water and $1 \mathrm{~mL} \mathrm{3 \%} \mathrm{2.3.5-tri-}$ phenyltetrazolium chloride (TTC) solution were mixed. After being incubated for $20 \mathrm{~h}$ at $30^{\circ} \mathrm{C}$, each sample was extracted with $25 \mathrm{~mL}$ ethanol for $1 \mathrm{~h}$ in the dark, and then filtrated. Finally, the absorption of soil extracts was determined at the wavelength of $485 \mathrm{~nm}$. Micrograms of produced triphenylformazan (TPF) per gram soil were used to express DH activity.

CAT activity in soil was determined according to Feigl et al. (2019). A soil suspension (consisting of $2 \mathrm{~g}$ soil, 40 $\mathrm{mL}$ distilled water and $5 \mathrm{~mL} 0.3 \% \mathrm{H}_{2} \mathrm{O}_{2}$ solution) was incubated for $20 \mathrm{~min}$, and then $5 \mathrm{~mL} 1.5 \mathrm{M} \mathrm{H}_{2} \mathrm{SO}_{4}$ was added. Filtrated suspensions were titrated with $0.02 \mathrm{M} \mathrm{KMnO}_{4}$ to eliminate residual $\mathrm{H}_{2} \mathrm{O}_{2}$. Results were presented as the reacting amount of permanganate calculated per dry soil weight. 


\section{Statistical analysis}

The nonparametric Mann-Whitney $U$ test was applied for comparing the distribution of the obtained data between the compost-amended $(n=10)$ and the control soils $(n=6)(p<$ 0.05 ) using the SPSS software (IBM SPSS Statistics, Version 24).

\section{Results and discussion}

\section{The effects of sewage sludge compost applications on the nutrient status and the heavy metal contents of soils}

The soils are characterized by a neutral to slightly alkaline $\mathrm{pH}$ (7.0-8.1), a little to medium organic matter content (1.53$2.55 \%$ ), a low carbonate content (0.14-3.56\%) and a sandy loam texture. Increased levels of $\mathrm{P}_{2} \mathrm{O}_{5}, \mathrm{~K}_{2} \mathrm{O}$ and $\mathrm{NO}_{2}{ }^{-}+$ $\mathrm{NO}_{3}{ }^{-}-\mathrm{N}$ nutrients can be observed in the compost-amended soil compared with the control site (Fig. 2). The statistically higher extractable amounts of N, P and K nutrients in treated soils can be explained by the slow decomposition of the compost that supplies bioavailable macronutrients for culture plants through their conversion into inorganic (and mostly plant available) forms by microorganisms (Diacono and Montemurro 2011). Elevated nitrate and ammonium concentrations have been detected in the groundwater under both the treated and the control sites that exceed the Hungarian environmental quality standards (Joint decree No. 6/2009. [IV. 14]) (Table 2). The advantageous use of sewage sludge composts compared with chemical fertilizers is supported by the lower dissolved nitrate concentration below the composttreated site. However, hardly any increase in the soil organic matter content can be highlighted between the compostamended and the control sites (Fig. 2). It has been previously suggested that significant changes in soil organic carbon contents due to repeated applications of organic amendments can only be observed after long time periods ( $>40$ years) (Gerzabek et al. 2001, Sleutel et al. 2006). In a 50-year-long field experiment in Hungary with Chernozem and Cambisols, it has been found that repeated applications of animal manure increased the soil organic carbon pool by 10 to $30 \%$ by applying respectively 40 to $80 \mathrm{t} /$ ha of fresh animal manure every 4 years (Sleutel et al. 2006). The lower fresh compost dose of 2.5 t/ha applied in 2013 and 2017 and the short treatment period explain the lack of a significant increase in the soil organic matter content of the compost-amended soils near Újkígyós.

The total $\mathrm{Cu}, \mathrm{Zn}, \mathrm{Co}, \mathrm{Ni}, \mathrm{Cr}$ and $\mathrm{Pb}$ contents of the treated and the control soils are shown in Fig. 3. According to our observations, it seems that in the short term (following two consecutive compost applications), no statistically significant metal enrichment can be noticed in the compost-amended soil for any of the examined metals. A slight (but not significant) increase in the top $30 \mathrm{~cm}$ in the soil-bound $\mathrm{Cu}$ and $\mathrm{Zn}$ contents can be noticed. Indeed, $\mathrm{Cu}$ and $\mathrm{Zn}$ are present in the sewage sludge compost in 5 to 15 times higher concentrations compared with those in the soil (Table 1). In the longer term, significant $\mathrm{Cu}$ and $\mathrm{Zn}$ accumulation are expected to occur in the soil affected by repeated applications of sewage sludge composts displaying similarly high $\mathrm{Cu}$ and $\mathrm{Zn}$ concentrations. However, the bioavailability of the slightly elevated $\mathrm{Cu}$ and $\mathrm{Zn}$ needs further investigations, as previous research has shown that biosolid-derived metals may present higher mobility and bioavailability in amended soils (Pinamonti et al. 1997). The potentially higher solubility of compost-derived metals can likely be affirmed by the elevated $\mathrm{Zn}, \mathrm{Cu}$ and $\mathrm{Ni}$ concentrations observed in the groundwater sample from the compost-treated site (Table 2). Hence, the repeated field applications of sewage sludge composts should be carefully managed in concern of avoiding accumulation and leaching of potentially toxic metals in compost-amended soils.

The addition of bioavailable nutrients and some soluble metal pollutants in agricultural soils via sewage sludge compost applications may influence biological patterns in the soil.

\section{The changes in microbiological soil properties in response to compost amendment}

The modification of bioavailable nutrient contents of agricultural soils and the introduction of metallic pollutants can induce remarkable changes in the microbiological soil properties. The mean aerobic microbial cell count was $8.25 \pm 4.19$ million CFUs per $\mathrm{g}$ in the amended soil, while $4.48 \pm 2.57$ million CFUs per $\mathrm{g}$ were enumerated in the control soil (Table 3). Although higher average aerobic CFUs characterized the sludge-treated soils, statistically no significant difference was observed between the treated and the control soils. Anaerobic microbial counts were determined from subsoil samples $(50-80 \mathrm{~cm})$ enumerating the groups of nitrate-, sulfate- and iron-reducing microorganisms (Table 3). Although the concentration of available macronutrients $(\mathrm{N}$, $\mathrm{P}, \mathrm{K}$ ) is higher in the compost-amended soil (Fig. 2), total anaerobic CFUs revealed to be lower compared with the control soil possibly due to the slight increase in the concentration of certain metallic elements. The predominant occurrences of iron-reducing and nitrate-reducing microbes were observed with the abundances of $5.79 \pm 1.56$ million CFUs and 6.69 \pm 0.09 million CFUs per g or $1.91 \pm 0.69$ million CFUs and $1.08 \pm 0.44$ million CFUs per $\mathrm{g}$ in control or treated soils, respectively. Varying degrees of decrease in anaerobic CFUs, in response to compost amendment, resulted in a relative enrichment of iron-reducing microorganisms in the anaerobic microbial community of the amended soil. 
Table 2 The dissolved nutrient concentrations and heavy metals in groundwater samples from compost-treated and control areas. The Hungarian standards for groundwater quality (Joint Decree No. 6/2009. [IV. 14.] KvVM-EüM-FVM) are also displayed

\begin{tabular}{lllllllllll}
\hline & $\mathrm{NO}_{3}{ }^{-}(\mathrm{mg} / \mathrm{l})$ & $\mathrm{NO}_{2}{ }^{-}(\mathrm{mg} / \mathrm{l})$ & $\mathrm{NH}_{4}{ }^{+}(\mathrm{mg} / \mathrm{l})$ & $\mathrm{PO}_{4}{ }^{3-}(\mathrm{mg} / \mathrm{l})$ & $\mathrm{Zn}(\mu \mathrm{g} / \mathrm{l})$ & $\mathrm{Pb}(\mu \mathrm{g} / \mathrm{l})$ & $\mathrm{Co}(\mu \mathrm{g} / \mathrm{l})$ & $\mathrm{Ni}(\mu \mathrm{g} / \mathrm{l})$ & $\mathrm{Cr}(\mu \mathrm{g} / \mathrm{l})$ & $\mathrm{Cu}(\mu \mathrm{g} / \mathrm{l})$ \\
\hline GW1 (compost-amended) & 92 & 0.4 & 2.2 & $<0.18$ & 20.9 & $<5.0$ & $<10$ & 24.4 & $<10$ & 11.4 \\
$\mathrm{GW}$ (control) & 312 & $<0.16$ & 0.8 & 0.22 & 1 & $<5.0$ & $<10$ & 5.5 & $<10$ & 1.9 \\
GW3 (control) & 112 & $<0.16$ & $<0.25$ & $<0.18$ & 3.6 & $<5.0$ & $<10$ & 4.3 & $<10$ & $<1.0$ \\
Hungarian standards & 50 & 0.5 & 0.5 & 0.5 & 200 & 10 & 20 & 20 & 50 & 200 \\
\hline
\end{tabular}

Changes in microbial cell counts often imply alterations in soil enzyme activities. In compost-amended soil, both the average catalase and dehydrogenase activities showed a slight increase but with no statistical significance (Table 3). Previous studies have reported that sewage sludge applications or irrigation using municipal wastewater has advantageous effects on the soil microbiological properties including DH and CAT activities due to the input of available nutrients, but this stimulation is not necessarily long lasting (Brzezińska et al. 2001, Lakhdar et al. 2010). It is also notable that both DH and CAT activities are extremely sensitive to the presence of heavy metals (Achuba and Peretiemo-Clarke 2008). Thus, the decreased values of both DH activity and CFUs in the anaerobic treated soil layer might be explained either by the time elapsed between the sewage sludge compost introduction and the soil sampling or even by the fact that these composts can contain toxic elements. Certain metabolites (such as sulfides) or heavy metal pollutants often have adverse effects on microbial activity (Chen et al. 2008). Our results indicate that the application of sewage sludge compost as a source of organic and inorganic nutrients does not have unfavorable impacts on soil microbiological parameters, moreover, it can stimulate the soil microbiome in the aerobic layer.

\section{Conclusions}

Organic amendments, such as municipal sewage sludge composts, influence soil propertied by inducing changes in their biological, chemical and physical attributes. Here, we showed that two consecutive applications of municipal sewage sludge composts at a low dose $(0.5 \mathrm{t} / \mathrm{ha})$ improved the soil nutrient status, by adding slowly decomposing organic matter abundant in macronutrients $(\mathrm{N}, \mathrm{K}, \mathrm{P})$ without causing excessive
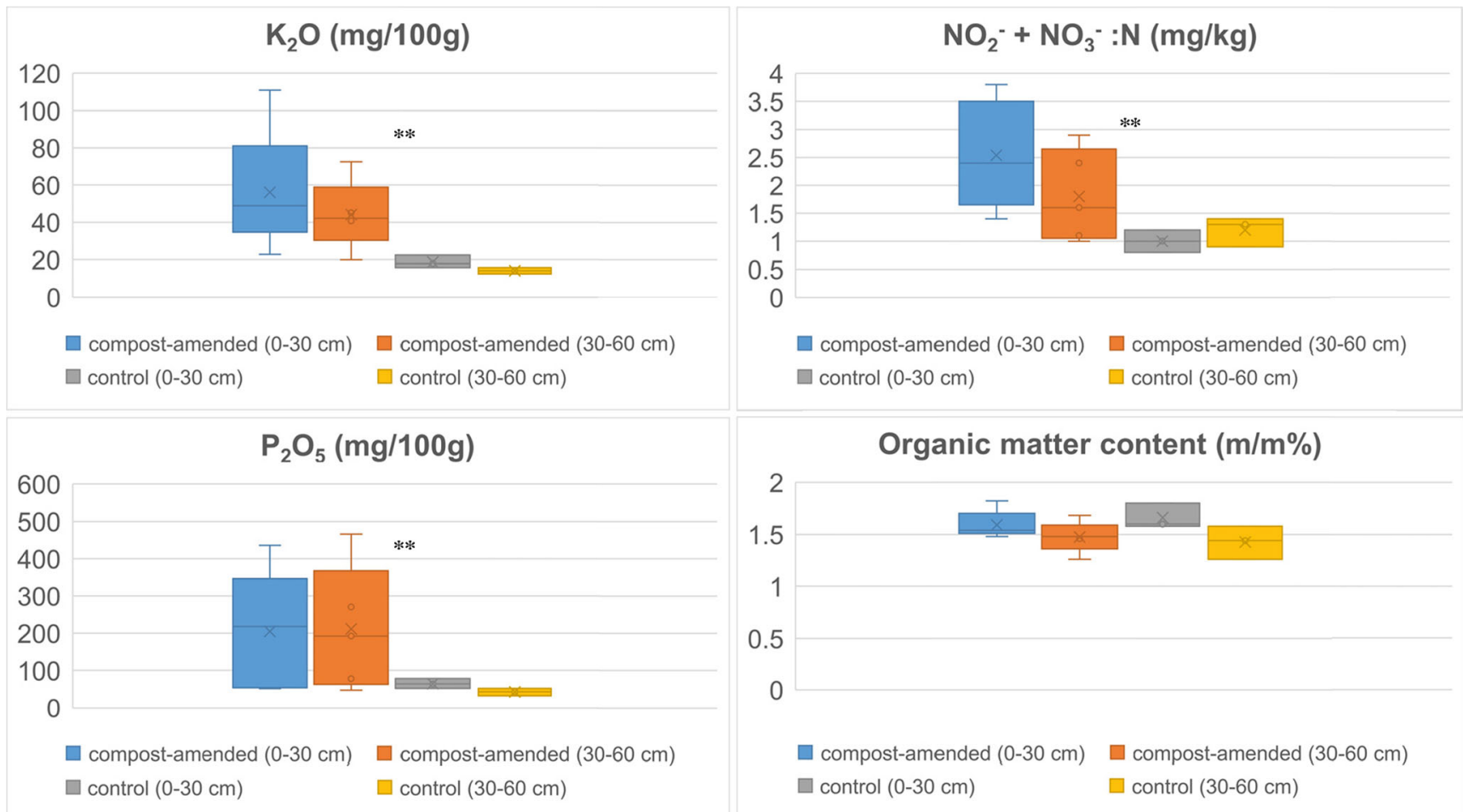

Fig. 2 The extractable nutrient $\left(\mathrm{K}_{2} \mathrm{O}, \mathrm{NO}_{2}{ }^{-}+\mathrm{NO}_{3}{ }^{-} \mathrm{N}, \mathrm{P}_{2} \mathrm{O}_{5}\right)$ contents and the organic matter contents in the compost-amended and the control soils. Double asterisks indicate significant difference between the compost-amended and the control sites $(p \leq 0.05)$ 


\section{$\mathrm{Cu}(\mathrm{mg} / \mathrm{kg})$}

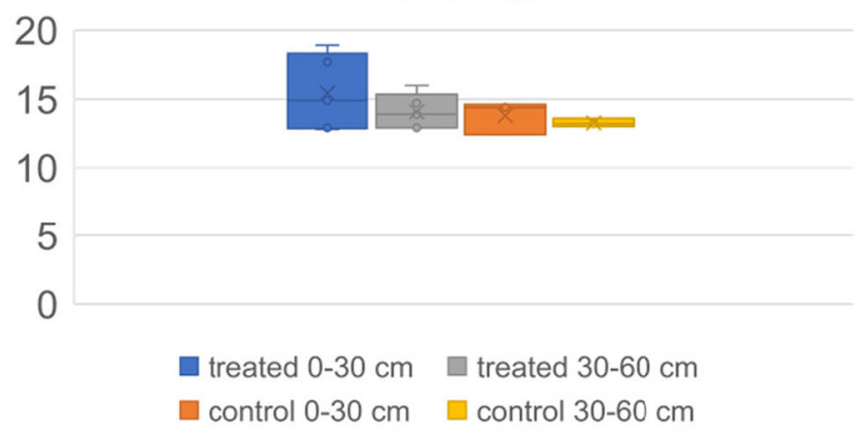

\section{Co $(\mathrm{mg} / \mathrm{kg})$}

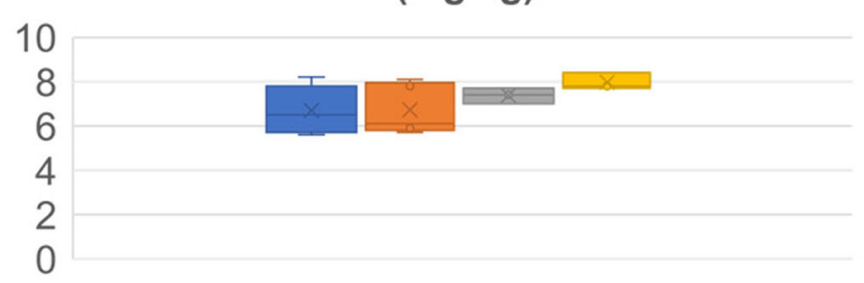

treated $0-30 \mathrm{~cm} \square$ treated $30-60 \mathrm{~cm}$

$\square$ control $0-30 \mathrm{~cm} \square$ control $30-60 \mathrm{~cm}$

\section{$\mathrm{Cr}(\mathrm{mg} / \mathrm{kg})$}

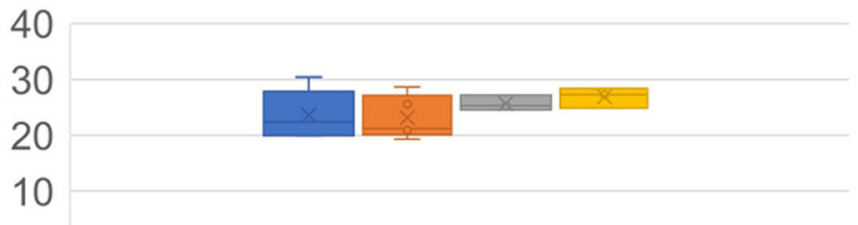

0
$\mathrm{Zn}(\mathrm{mg} / \mathrm{kg})$

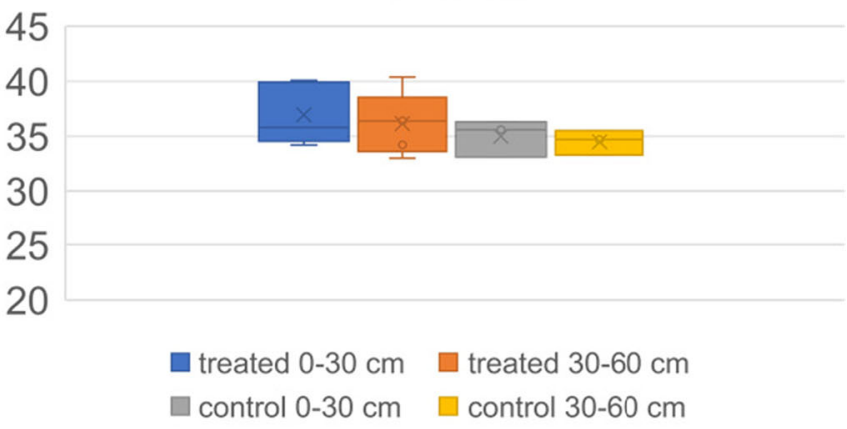

$\mathrm{Ni}(\mathrm{mg} / \mathrm{kg})$

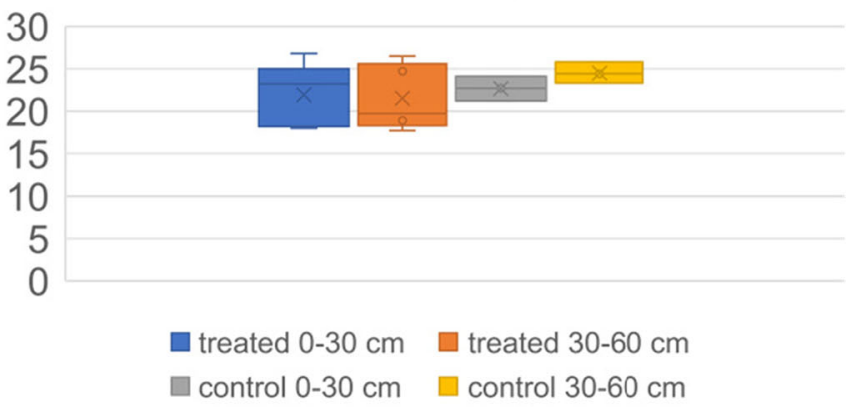

$\mathrm{Pb}(\mathrm{mg} / \mathrm{kg})$

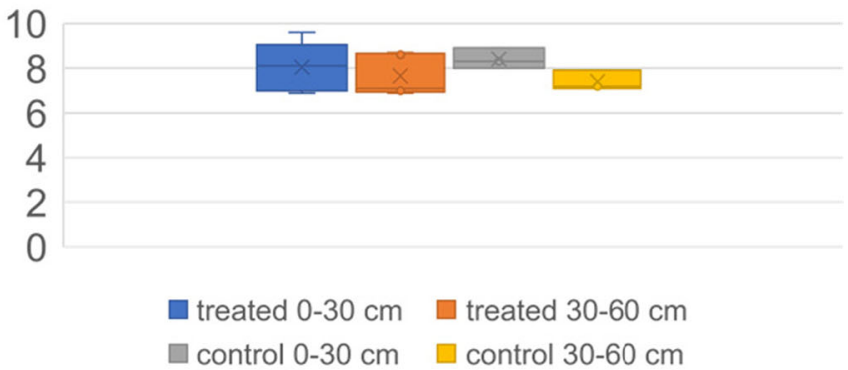

Fig. 3 The total heavy metal contents in the compost-amended and the control soils

leaching of nitrate into the groundwater. Although microbial cell counts and DH enzyme activity in the anaerobic soil layers did not increase in the compost-amended soils, aerobic CFUs and soil enzyme activities (both DH and CAT) tended to be higher in the treated soils compared with the non- amended (control) site, however not significantly. These results suggest that the soil biological activity is only moderately but positively affected by the compost applications. Here, the low-dose application of the municipal sewage sludge compost seems to be an environmentally sound land management

Table 3 Microbial counts (CFUs), catalase (CAT) and dehydrogenase (DH) activities of sewage sludge compost-amended and control soils in aerobic and anaerobic soil layers

\begin{tabular}{|c|c|c|c|c|c|c|c|}
\hline & & \multicolumn{2}{|c|}{ Microbial counts (million CFUs per g) } & \multicolumn{2}{|l|}{ DH ( $\mu \mathrm{g}$ TPF/g/24 h) } & \multicolumn{2}{|c|}{$\mathrm{CAT}\left(\mu \mathrm{mol} \mathrm{H}{ }_{2} \mathrm{O} / \mathrm{g} / \mathrm{min}\right)$} \\
\hline & & Compost-amended & Control & Compost-amended & Control & Compost-amended & Control \\
\hline \multirow[t]{2}{*}{ Aerobic } & & $8.25 \pm 4.19$ & $4.48 \pm 2.57$ & $33.76 \pm 4.60$ & $31.48 \pm 13.39$ & $11.93 \pm 1.16$ & $11.02 \pm 0.29$ \\
\hline & Nitrate-red. & $1.08 \pm 0.44$ & $6.69 \pm 0.09$ & & & & \\
\hline \multirow[t]{2}{*}{ Anaerobic } & Sulfate-red. & $0.04 \pm 0.01$ & $1.98 \pm 0.52$ & $14.27 \pm 1.24$ & $18.96 \pm 2.92$ & $11.06 \pm 1.14$ & $10.09 \pm 0.15$ \\
\hline & Iron-red. & $1.91 \pm 0.69$ & $5.79 \pm 1.56$ & & & & \\
\hline
\end{tabular}


practice that supplies macronutrients without the excessive addition of heavy metal pollutants into the agricultural soil.

Funding Open access funding provided by University of Szeged. The research was funded by the 'Thematic Network for the Sustainable Use of Re-sources - RING2017' project (program code: EFOP-3.6.2-16201700010). I.B. is grateful for the support of the Premium Postdoctoral Research Program of the Hungarian Academy of Sciences.

Open Access This article is licensed under a Creative Commons Attribution 4.0 International License, which permits use, sharing, adaptation, distribution and reproduction in any medium or format, as long as you give appropriate credit to the original author(s) and the source, provide a link to the Creative Commons licence, and indicate if changes were made. The images or other third party material in this article are included in the article's Creative Commons licence, unless indicated otherwise in a credit line to the material. If material is not included in the article's Creative Commons licence and your intended use is not permitted by statutory regulation or exceeds the permitted use, you will need to obtain permission directly from the copyright holder. To view a copy of this licence, visit http://creativecommons.org/licenses/by/4.0/.

\section{References}

Abubakari M, Moomin A, Nyarko G, Dawuda MM (2017) Heavy metals concentrations and risk assessment of roselle and jute mallow cultivated with three compost types. Ann Agric Sci 62(2):145-150. https://doi.org/10.1016/j.aoas.2017.11.001

Achuba F, Peretiemo-Clarke B (2008) Effect of spent engine oil on soil catalase and dehydrogenase activities. Int Agrophys 22(1):1

Aggelides SM, Londra PA (2000) Effects of compost produced from town wastes and sewage sludge on the physical properties of a loamy and a clay soil. Bioresour Technol 71(3):253-259. https:// doi.org/10.1016/S0960-8524(99)00074-7

Banerjee MR, Burton DL, Depoe S (1997) Impact of sewage sludge application on soil biological characteristics. Agric Ecosyst Environ 66(3):241-249. https://doi.org/10.1016/S0167-8809(97) 00129-1

Bodor A, Bounedjoum N, Vincze GE, Erdeiné Kis Á, Laczi K, Bende G, Szilágyi Á, Kovács T, Perei K, Rákhely G (2020) Challenges of unculturable bacteria: environmental perspectives. Rev Environ Sci Biotechnol 19(1):1-22. https://doi.org/10.1007/s11157-02009522-4

Brzezińska M, Stępniewska Z, Stępniewski W (2001) Dehydrogenase and catalase activity of soil irrigated with municipal wastewater. Pol J Environ Stud 10(5):307-311

Chen Y, Cheng JJ, Creamer KS (2008) Inhibition of anaerobic digestion process: a review. Bioresour Technol 99(10):4044-4064. https:// doi.org/10.1016/j.biortech.2007.01.057

Dhaliwal SS, Naresh RK, Gupta RK, Panwar AS, Mahajan NC, Singh R, Mandal A (2020) Effect of tillage and straw return on carbon footprints, soil organic carbon fractions and soil microbial community in different textured soils under rice-wheat rotation: a review. Rev Environ Sci Biotechnol 19(1):103-115. https://doi.org/10.1007/ s11157-019-09520-1

Diacono M, Montemurro F (2011) Long-term effects of organic amendments on soil fertility. In: Lichtfouse E, Hamelin M, Navarrete M, Debaeke P (eds) Sustainable Agriculture, vol 2. Springer Netherlands, Dordrecht, pp 761-786. https://doi.org/10.1007/97894-007-0394-0_34

Farkas M, Szoboszlay S, Benedek T, Revesz F, Veres PG, Kriszt B, Tancsics A (2017) Enrichment of dissimilatory Fe(III)-reducing bacteria from groundwater of the Siklos BTEX-contaminated site (Hungary). Folia Microbiol 62(1):63-71. https://doi.org/10.1007/ s12223-016-0473-8

Feigl G, Molnar A, Szollosi R, Ordog A, Torocsik K, Olah D, Bodor A, Perei K, Kolbert Z (2019) Zinc-induced root architectural changes of rhizotron-grown B. napus correlate with a differential nitrooxidative response. Nitric Oxide 90:55-65. https://doi.org/10. 1016/j.niox.2019.06.003

Frîncu M, Dumitrache C, Dumitru A, Cimpeanu P, Mihai L (2015) Soil fertility assessment through enzyme activity. J Young Sci 3:12831291

Gerzabek MH, Haberhauer G, Kirchmann H (2001) Soil organic matter pools and carbon-13 natural abundances in particle-size fractions of a long-term agricultural field experiment receiving organic amendments. Soil Sci Soc Am J 65(2):352-358. https://doi.org/10.2136/ sssaj2001.652352x

Gong W, Yan X, Wang J, Hu T, Gong Y (2009) Long-term manure and fertilizer effects on soil organic matter fractions and microbes under a wheat-maize cropping system in northern China. Geoderma 149(3):318-324. https://doi.org/10.1016/j.geoderma.2008.12.010

Government Decree No. 50/2001 (IV. 3.) regulating the agricultural use and management of wastewater and sewage sludge

Guo L-J, Zhang Z-S, Wang D-D, Li C-F, Cao C-G (2015) Effects of short-term conservation management practices on soil organic carbon fractions and microbial community composition under a ricewheat rotation system. Biol Fertil Soils 51(1):65-75. https://doi.org/ 10.1007/s00374-014-0951-6

Guo L-J, Lin S, Liu T-Q, Cao C-G, Li C-F (2016) Effects of conservation tillage on topsoil microbial metabolic characteristics and organic carbon within aggregates under a rice (Oryza sativa L.)-wheat (Triticum aestivum L.) cropping system in central China. PLoS One 11(1):e0146145. https://doi.org/10.1371/journal.pone.0146145

Joint Decree No. 6/2009 (IV. 14) KvVM-EüM-FVM of the Ministers of Environmental Protection and Water Management, Public Health, Agriculture and Regional Development on the limit values necessary to protect the quality of geological medium and the groundwater and on measurement of pollution

Laczi K, Kis Á, Horváth B, Maróti G, Hegedüs B, Perei K, Rákhely G (2015) Metabolic responses of Rhodococcus erythropolis PR4 grown on diesel oil and various hydrocarbons. Appl Microbiol Biotechnol 99(22):9745-9759. https://doi.org/10.1007/s00253015-6936-Z

Ladányi Zs, Farsang A, Gulácsi A, Kovács F (2018) The impact of extreme weather conditions and municipal sewage disposal on vegetation using sentinel images, SE Hungary. Proceedings of the International Symposium on Analytical and Environmental Problems (24), p 325-329.

Lakhdar A, Scelza R, Scotti R, Rao MA, Jedidi N, Gianfreda L, Abdelly $C$ (2010) The effect of compost and sewage sludge on soil biologic activities in salt affected soil. Revista de la ciencia del suelo y nutrición vegetal 10:40-47. https://doi.org/10.4067/S071827912010000100005

McGrath SP, Zhao FJ, Dunham SJ, Crosland AR, Coleman K (2000) Long-term changes in the extractability and bioavailability of zinc and cadmium after sludge application. J Environ Qual 29(3):875883. https://doi.org/10.2134/jeq2000.00472425002900030025x

MSZ-08-0206-2 Evaluation of Some Chemical Properties of the Soil. Laboratory Tests. ( $\mathrm{pH}$ value, phenolphtaleine alkalinity expressed in soda, all water soluble salts, hydrolite (y1-Value) and exchanging acidity (y2-Value)). Hungarian Standard Association, Budapest (1978) (in Hungarian)

MSZ 21470-52 Environmental Protection. Testing of Soils. Determination of organic matter. Hungarian Standard Association, Budapest (1983) (in Hungarian)

Pinamonti F, Stringari G, Gasperi F, Zorzi G (1997) The use of compost: its effects on heavy metal levels in soil and plants. Resour Conserv 
Recycl 21(2):129-143. https://doi.org/10.1016/S0921-3449(97) 00032-3

Qi G, Jia Y, Liu W, Wei Y, Du B, Fang W, Guo Y, Guo F, Wu Y, Zou Q, Liu J (2020) Leaching behavior and potential ecological risk of heavy metals in Southwestern China soils applied with sewage sludge compost under acid precipitation based on lysimeter trials. Chemosphere 249:126212. https://doi.org/10.1016/j.chemosphere. 2020.126212

Sambrook J, Fritsch EF, Maniatis T (1989) Molecular cloning: a laboratory manual. Cold Spring Harbor Laboratory Press, Cold Spring Harbor

Sleutel S, De Neve S, Németh T, Tóth T, Hofman G (2006) Effect of manure and fertilizer application on the distribution of organic carbon in different soil fractions in long-term field experiments. Eur J Agron 25(3):280-288. https://doi.org/10.1016/j.eja.2006.06.005

Wang Y, Hu N, Ge T, Kuzyakov Y, Wang Z-L, Li Z, Tang Z, Chen Y, Wu C, Lou Y (2017) Soil aggregation regulates distributions of carbon, microbial community and enzyme activities after 23-year manure amendment. Appl Soil Ecol 111:65-72. https://doi.org/10. 1016/j.apsoil.2016.11.015

Wolinska A, Kuzniar A, Szafranek-Nakonieczna A, Jastrzebska N, Roguska E, Stepniewska Z (2016) Biological activity of autochthonic bacterial community in oil-contaminated soil. Water Air Soil Pollut 227:130. https://doi.org/10.1007/s11270-016-2825-Z

Wu M, Chen L, Tian Y, Ding Y, Dick WA (2013) Degradation of polycyclic aromatic hydrocarbons by microbial consortia enriched from three soils using two different culture media. Environ Pollut 178: 152-158. https://doi.org/10.1016/j.envpol.2013.03.004

Xue D, Huang X (2013) The impact of sewage sludge compost on tree peony growth and soil microbiological, and biochemical properties. Chemosphere 93(4):583-589. https://doi.org/10.1016/j. chemosphere.2013.05.065 